\title{
PLURIATIVIDADE NO CONTEXTO DA REGIÃO METROPOLITANA DE CURITIBA-PR
}

\author{
José Roberto da Fonte \\ Orientador: Prof. Dr. Valdo José Cavallet
}

\begin{abstract}
RESUMO
A revolução verde acumulou dois desencantos: não previu que além de produzir, era necessário que esta riqueza fosse distribuída. O segundo foi de que a tecnologia de produção, nos países em desenvolvimento, não pôde ser bancada e a miséria ainda persiste. Tornou-se um consenso que o desenvolvimento agrícola não levou a um desenvolvimento rural e isto pode ser constatado pela concentração de terras, rendas e salários. Por outro lado, o meio rural está recebendo novas funções e ocupações e não pode ser mais visto apenas como um lugar onde se produz mercadorias agrícolas, minerais ou mão-de-obra barata. O meio rural pode oferecer além de alimentos de qualidade, lazer, saúde, turismo e postos de trabalho. Para definir este conjunto de atividades foi adotado o termo pluriatividade, que toma como unidades de análise a família e a geração de renda não agrícolas. Na Região Metropolitana de Curitiba estas outras atividades no meio rural estão se tornando parte na solução de um grande desafio: o abastecimento com produtos agrícolasn para uma população de cerca de 2,5 milhões de habitantes, a degradação dos recursos naturais causadas por esta exploração agrícola e a busca do desenvolvimento rural. O presente estudo mostrou ainda outros agravantes: na Região Metropolitana de Curitiba a brutal taxa de crescimento em alguns dos seus municípios está gerando conflitos pela ocupação do espaço, está ocorrendo a degradação dos recursos hídricos pelos agrotóxicos e fertilizantes, a erosão do solo, os resíduos orgânicos e ainda a disputa pelo uso da água. Apesar da manutenção da integridade dos seus mananciais, as atuais reservas de água deverão estar esgotadas em 25 anos. Pretendeu-se discutir neste trabalho, além do estudo dos aspectos acima citados, a formação profissional do engenheiro agrônomo de maneira integrada às novas realidades da Região Metropolitana de Curitiba.
\end{abstract}

\begin{abstract}
The Green Revolution accumulated two disenchantments: one was that it did not foresee that besides production, distribution of this wealth was necessary. The second was that the production technology, in developing countries, could not be paid off, and that poverty still persists. It became a consensus that the agricultural improvement did not lead to rural development. This can be observed by land concentration, incomes and salaries. On the other hand, the rural area is receiving new functions and occupations, and it can not be seen just as a place for agricultural production, source of mineral goods, or cheap labor. Besides quality food production, the rural areas can offer other alternatives as leisure, tourism and jobs. To define this multitude of activities, the term pluri-activity was coined. This term takes as units of analysis, family and non agricultural income generation. In Curitiba Metropolitan rural areas these other sources of activities are becoming part in the solution of a great challenge: the source of food supply for about 2.5 million inhabitants, natural resource degradation caused by this agricultural exploration and the search for rural development. The present study, in the Curitiba Metropolitan Area, also showed still other bottlenecks: abnormally high growth rate in some of their municipal districts generating conflicts by space occupation, degradation of water resources by pesticides and fertilizers, soil erosion, organic residues accumulation and still the struggle for water usage. In spite of keeping the water reservoirs integrity, the present water sources should be exhausted within a 25 year span. Besides discussing the above mentioned trouble related aspects, the present study also intended to link the formation of a general agricultural professional with his integration to the new reality of the Curitiba Metropolitan Area.

Key-words: Rural employment, environmental degradation, rural extension, plant production, agronomy.
\end{abstract}

